\title{
Assessment of Household Access to Groundwater: A Case Study of Gilgil Constituency
}

\author{
Jenipher Achieng' Obiero, Mercy Mwaniki, Benson Kipkemboi Kenduiywo \\ Department of Geomatics Engineering \& Geospatial Information Systems, Jomo Kenyatta University of Agriculture and \\ Technology, Nairobi, Kenya \\ Email: chngnel@yahoo.com
}

How to cite this paper: Obiero, J.A., Mwaniki, M. and Kenduiywo, B.K. (2019) Assessment of Household Access to Groundwater: A Case Study of Gilgil Constituency. Journal of Geographic Information System, 11, 293-308.

https://doi.org/10.4236/jgis.2019.113017

Received: April 17, 2019

Accepted: May 13, 2019

Published: May 16, 2019

Copyright $\odot 2019$ by author(s) and Scientific Research Publishing Inc. This work is licensed under the Creative Commons Attribution International License (CC BY 4.0).

http://creativecommons.org/licenses/by/4.0/

\begin{abstract}
In 2000, the United Nations (UN) developed Millennium Development Goals (MDG) with one of its aim being to improve access of potable water supply by 2015 in developing countries. This study thus focused on Kenya's Gilgil constituency which lies in both arid and semi-arid zones and experiences bimodal rains which are neither heavy nor reliable. With persistent shortages, water management and monitoring became essential and in current times the use of Geographic Information Systems (GIS) is being incorporated due to its capability as an effective tool in water resources management. The study's aim was to provide knowledge about accessible areas and gaps using cost surface analysis as well as identify other factors that influence settlement. The study utilized walk speeds as an impedance to determine cost surfaces followed by creation of service areas from water facilities using time as a measurement of access. The study established that surface friction may not have major influence on accessibility and service areas while logistic regression established that other factors strongly influence settlement apart from water availability. The study also reveals that $77 \%$ of the semi-permanent households in Gilgil have a hard time accessing water as they are outside the 30-minute walk time.
\end{abstract}

\section{Keywords}

Geography Information Systems, Water Accessibility, Service Area, Logistic Regression, Ground Water

\section{Introduction}

Globally a country is categorized as "water stressed" if its annual renewable 
freshwater supplies are between 1000 and $1700 \mathrm{~m}^{3}$ per capita per annum and "water scarce" if its renewable freshwater supplies are less than $1000 \mathrm{~m}^{3}$ per capita per annum [1]. Worldwide, an estimated 768 million people are not able to access improved source of water either surface or groundwater [2]. Groundwater has become a significant source of water for human consumption, supplying nearly half of the world's drinking water [3], yet groundwater supplies are diminishing with an estimated $20 \%$ of the world's aquifers currently over-exploited [4].

In Africa, about $66 \%$ of the land is arid or semi-arid and more than 300 of the 800 million people in sub-Saharan Africa live in a water-scarce environment hence they have less than 1000 per capita [5]. According to World Health Organization (WHO) and United Nations Children's Fund (UNICEF), 44\% of the world's population who are mainly from Southern Asia and Sub-Saharan Africa leave their homes and walk for more than an hour to "non-networked" water supplies to fetch water for drinking and other domestic uses [6]. It is believed that households whose water sources are located more than 30 minutes away in most instances collect less water that may not be enough for their daily basic needs [7]. World Bank stated that about 15\% of households in Africa receive piped water connected into houses; another $15 \%$ obtain water from vendors; $37 \%$ obtain from Wells and boreholes making them the most common form of water supply in the region. The rest of the population thus relies on surface water [8].

In 2013, Kenya's Ministry of Environment Report [9] stated that the country's surface water resources were estimated to be 22,564 million $\mathrm{m}^{3}$ representing $91.5 \%$ of the total available water resources, the rest being groundwater. In 2010, Kenya's available freshwater resources index was estimated to be 1093 $\mathrm{m}^{3} /$ capita/year while water resources availability was $586 \mathrm{~m}^{3} / \mathrm{capita} /$ year and projected to fall to $235 \mathrm{~m}^{3}$ by 2020 [10]. In 1992, a study was conducted that the government had no ability to properly fund and operate water services which contributed to low levels of water resource management, low storage, inadequate improved water sources as well as inefficient data management [9]. In 2002, the Kenyan Water Act was implemented to help improve efficiency and minimize duplication of duties by separating and decentralizing functions of different water institutions and stakeholders [11].

To further improve water management, technology has been incorporated like the use of Remote sensing and Geographic Information Systems (GIS) which is applied in different ways in the water sector that include asset management, distribution management, and customer management. The aim of this paper is to illustrate the use of GIS in identifying and measuring levels of pedestrian accessibility by computing travel costs to obtain travel time zones.

In the recent past, there have been several studies conducted in Africa on water accessibility and coverage; Ntozini in 2015 [12] did a study in Zimbabwe that estimated access and sanitation of specific treatment clusters in the population and made use of Google Earth imagery to identify settlements within the study area and used shortest distance analysis to establish coverage. In 2010, another study was done in Nigeria [13] that set to establish accessibility using explorato- 
ry and descriptive approaches and GIS to map out the study area based on levels of access to potable water. In Kenya, an accessibility study was done in Kisumu [14] and the focus was to assess accessibility to water services by income categories which used stratified random sampling and Analysis of Variance (ANOVA) technique for analysis.

This study seeks to improve on Ntozini approach in identifying water coverage by instead using high resolution aerial imagery of $15 \mathrm{~m}$ to identify semi-permanent households which is the population likely to walk in search of water facilities. Ntozini observed access in terms of shortest distance only while this study will incorporate infrastructure availability, slope and landcover to ascertain walk speeds and then use cost distance analysis and service areas to demarcate coverage in terms of time.

\section{Materials and Methods}

\subsection{Study Area}

The study area adopted is Gilgil constituency shown in Figure 1. It is an electoral region of Nakuru County with a population of 152,102 with five wards Kiambogo, Malewa West, Gilgil, Mbaruk and Murindat [15]. It lies on latitude 0 degrees 16 minutes South and longitude 36 degrees 04 minutes East with an administrative area of about 1348 Sq. Km within Universal Transverse Mercator (UTM) of zone 37 South.

The study area is covered by rivers and consists of Lake Elementaita and surrounded by Lake Naivasha and Lake Nakuru. The rocks underlying the study area are volcanic rock deposits which have low permeability and storage capacity that feeds the groundwater system from high precipitation at higher altitudes

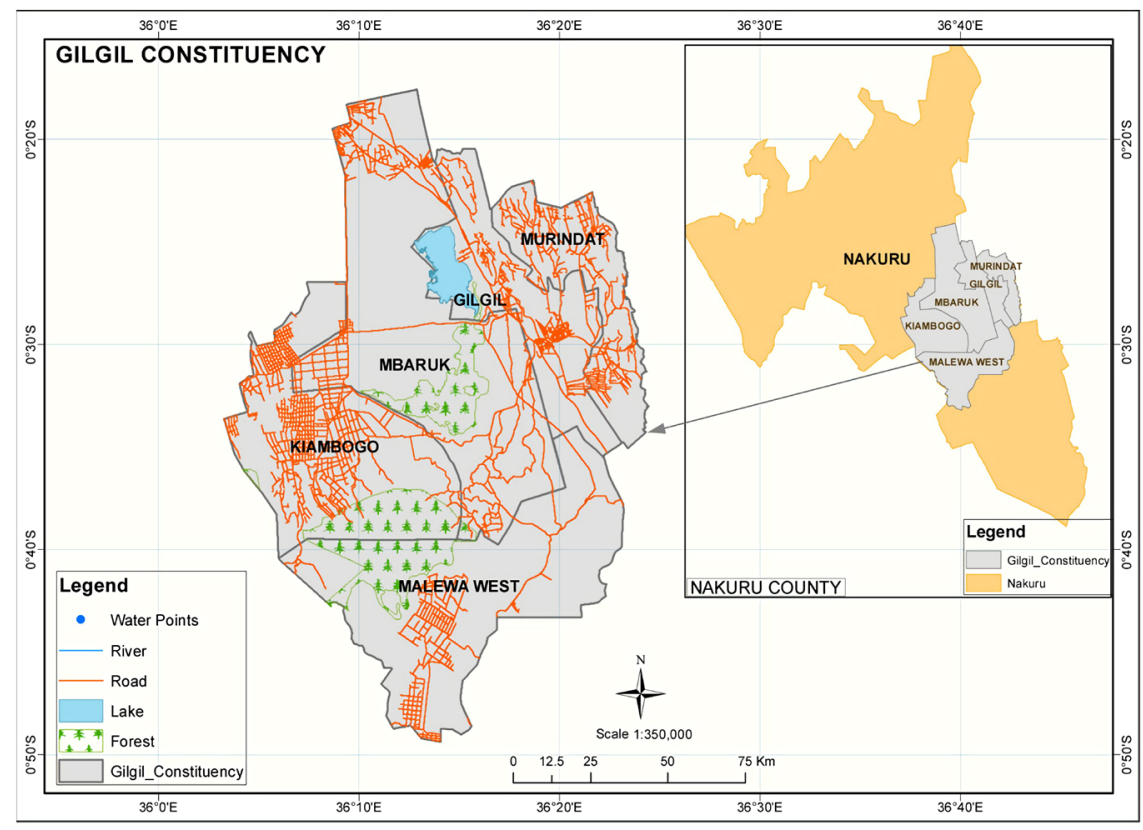

Figure 1. Study area; Gilgil constituency. 
[16]. Groundwater gained from recharge flows longitudinally from these highland areas to the valley floor, following surface elevation contours [13]. The rainfall pattern in Gilgil is bimodal with rainy seasons from April to June (long rain) and from October to November (short rain) and the mean annual temperature lies between 10 and 21 degrees Celsius conditions that are likely to promote rainfall shortages [17] [18].

Gilgil constituency was selected since a water study on accessibility has not been conducted though many studies have been done on the lakes within and around the area, considering the geology of the area that has resulted in high fluorides being experienced in the groundwater. This study used water points tested and accepted by Water Resource Management Authority (WRMA) to establish accessibility to these water points by pedestrians. The area was also suitable for accessibility study due to its diverse terrain that enabled assessment of different walk speeds with different slope angles.

\subsection{Data Collection}

Datasets used in this research were landcover, Digital Elevation Model (DEM) where slope was extracted, household locations; where semi-permanent structures were extracted from aerial photos through digitization. Vector datasets used were: transport network (road and railway), water facility points which included boreholes and a few springs and areas demarcated and set aside for specific usage under government directives which may deter or encourage settlement with or without water facilities present; Table 5 shows these datasets and their sources.

Household data was digitized from geo-rectified and geo-referenced aerial imagery of $15 \mathrm{~m}$ spatial resolution. All buildings were identified and semi-permanent structures differentiated from permanent households by use of size, shape, height and proximity of the structures. The study is interested with semi-permanent structures since it's the population that is likely to use potable water. These semi-permanent structures were captured as polygons and represented as points by use of a conversion tool that captures the points as centroids.

Water facility locations which included mainly boreholes were obtained from Water Resource Management Authority (WRMA) and these water points are

Table 1. Shows the percentages per each source but not all sources were indicated for use in this study.

\begin{tabular}{cccccc}
\hline $\begin{array}{c}\text { Gilgil } \\
\text { Constituency }\end{array}$ & River & $\begin{array}{c}\text { Unprotected } \\
\text { Spring }\end{array}$ & Vendor & $\begin{array}{c}\text { Unimproved } \\
\text { Sources }\end{array}$ & Borehole \\
\hline Gilgil & 0.7 & 1.5 & 15.4 & 18.3 & 0.9 \\
Kiambogo & 11.4 & 3.2 & 1 & 17.6 & 35.7 \\
Mbaruk & 9.4 & 3.1 & 10.5 & 42.1 & 19.4 \\
Malewa West & 3.1 & 0.5 & 1.9 & 8.7 & 33.9 \\
Murindat & 37.2 & 7.7 & 3.5 & 64.7 & 0.5 \\
\hline
\end{tabular}


monitored and controlled for quality hence the aspect of quality was not examined in the study. The points had locational information and was obtained in form of an excel sheet and captured as a shapefile to map them within the study area as shown in Figure 2.

The road network was obtained from United Nations Office for the Coordination of Humanitarian Affairs (UNOCHA) Rosea open source portal. The road network was categorized into classes of main road, secondary road and tracks. These classes were given pedestrian walk speeds as shown in Table 2 while the main road was eliminated from analysis since it's not expected for people to actively use that class of road while on foot. Documented data on travelling times in Kenya is very limited hence travelling times were adopted from the work of Pozzi and Robinson [19] as shown in Table 2.

The slope on the other hand was obtained from the digital elevation model

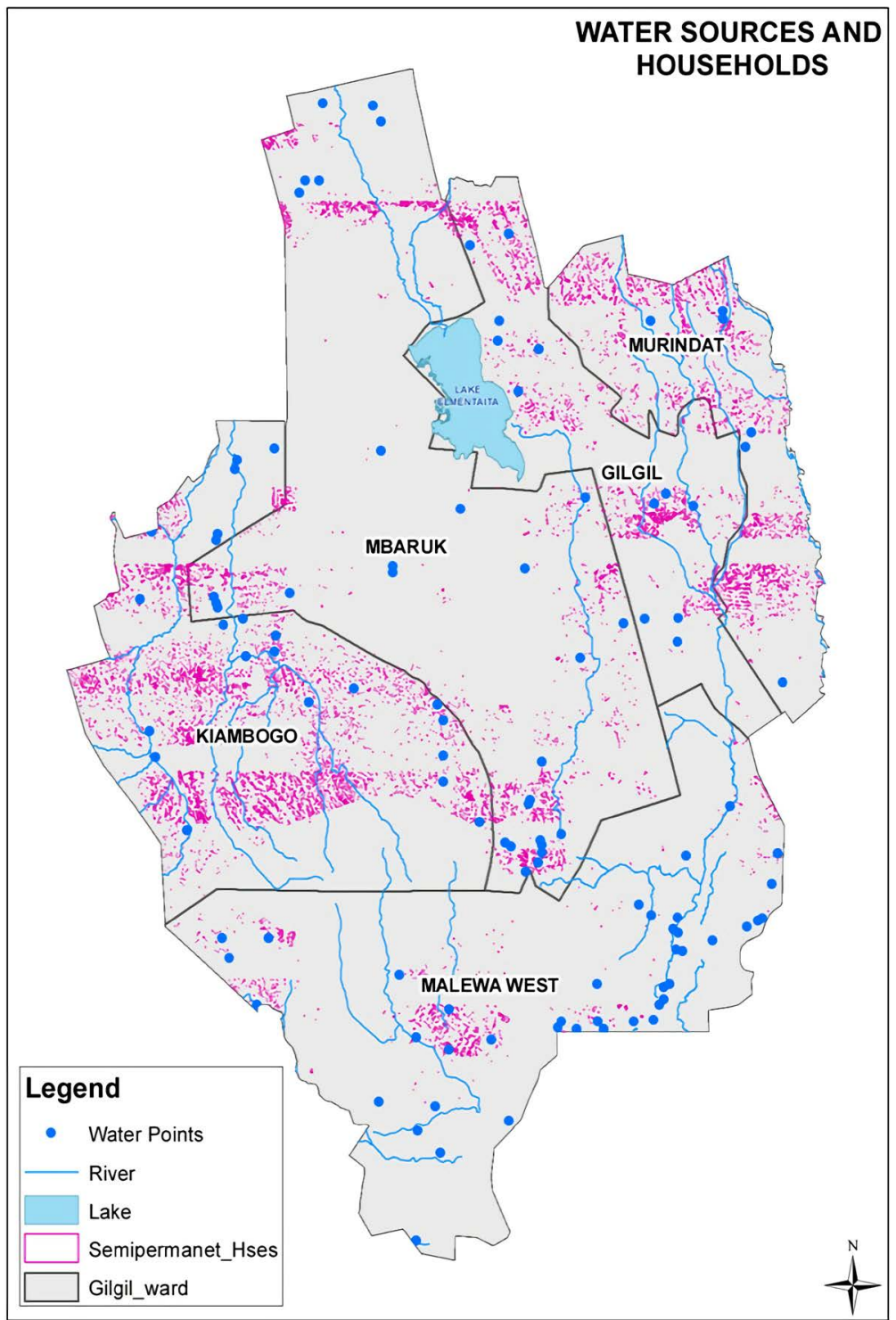

Figure 2. Water sources and households. 
Table 2. Showing road type and walk speeds.

\begin{tabular}{cl}
\hline Road Type & Walking \\
\hline Primary Road & $5 \mathrm{Km} / \mathrm{hr}$ \\
Secondary Road & $4 \mathrm{Km} / \mathrm{hr}$ \\
Tertiary Road & $3 \mathrm{Km} / \mathrm{hr}$ \\
Tracks & $2 \mathrm{Km} / \mathrm{hr}$ \\
\hline
\end{tabular}

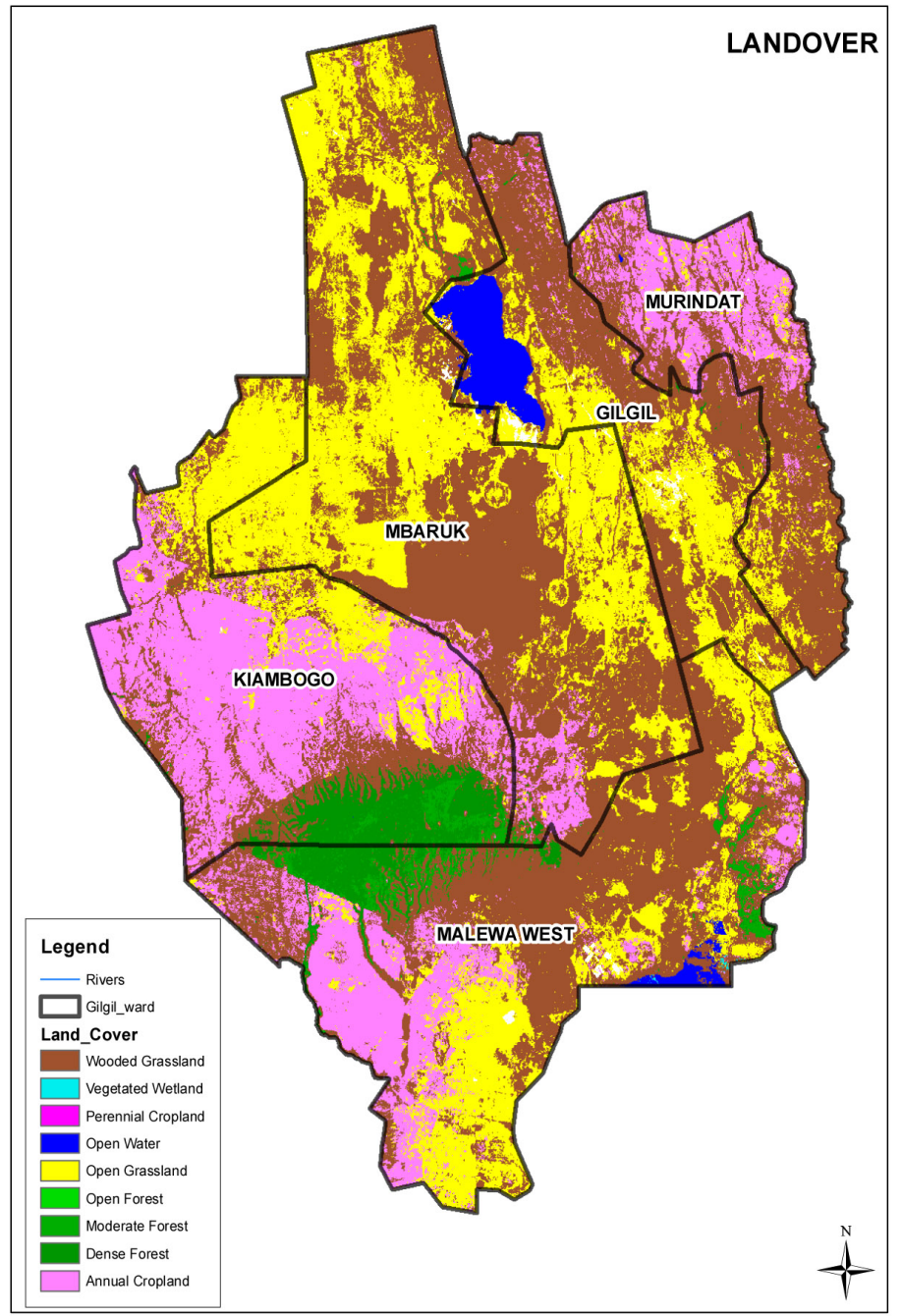

Figure 3. Land cover.

(DEM) of a Shuttle Radar Topography Mission (SRTM) of $15 \mathrm{~m}$. The slopes were allocated walking speed as shown in Table 3 with walk speeds assigned at specific degree of slope adopted from Alegana's work [20]. As for land cover, various speeds were also allocated and the speeds were borrowed from previous studies that had estimated walk speeds on different land covers as adopted from Pozzi and Robinson [21] as shown in Table 4. The study also sought to determine why people would settle in areas with scarce water resource hence areas that the government has demarcated for other activities like forests, wetlands, 
Table 3. Walk speeds on different degree of slope adopted from Alegana [20].

\begin{tabular}{cccc}
\hline Feature & Classification & Speed $\mathrm{Km} / \mathrm{h}$ & Model \\
\hline Digital Elevation Model & Degree of Slope & & \\
$<0.5^{\circ}$ & 4.88 & Walking \\
$5^{\circ}$ & 3.71 & Walking \\
$10^{\circ}$ & 2.71 & Walking \\
$20^{\circ}$ & 1.41 & Walking \\
$30^{\circ}$ & 0.66 & Walking \\
\hline
\end{tabular}

Table 4. Showing land cover and walk speeds adopted from Pozzi and Robinson [21].

\begin{tabular}{cc}
\hline Land Cover & Walk Speeds $(\mathrm{Km} / \mathrm{hr})$ \\
\hline Sparse/Open Grasslands, Shrubs & 3 \\
Bare Soil & 5 \\
Woodland & 2 \\
Swamps & 1 \\
Forest Cover & 1.5 \\
Water Bodies & 0 \\
Cultivated Lands & 5 \\
Urban and Built-up Areas & 5 \\
\hline
\end{tabular}

settlement schemes were established and used in the logistic regression analysis.

\subsection{Methods}

The study adopted cost distance analysis using time as the cost. Cost distance tool was selected due to its capability to combine weights of different surfaces as one moves through each cell location and create a suitable model for walking analysis. We evaluated focal statistics values for land cover layer, slope and built-up area developed from the aerial image that were converted to raster and accorded varying importance using Visual Basic (VB) script. We eliminated primary roads from the road data as they cannot serve as walkable routes. The resulting raster was then classified from 1 to 10 based on difficulty of travel, with a value of 1 being easiest to travel and 10 being most difficult.

The weighted sum overlay of the layers involved set conditions such that if a cell contained a variable like a water body which is not conducive for walking then the summation with the other cell values still acquired or retained the level of difficulty of the water body cell or other variable used containing highest difficulty rate; otherwise the cell values were averaged to obtain the new values. Thereafter, groundwater locations were loaded and a path distance raster was created showing the travel costs. The cost distance tool requires source locations which were the water points and a cost raster which was the combined weight raster as input shown in Figure 4. 
Table 5. Data sources and spatial resolution.

\begin{tabular}{cccc}
\hline Category & Data & Resolution & Sources \\
\hline Transport Network & Railway & & UNOCHA Rosea \\
& Road Network & & Kenya Roads Board \\
Digital Elevation Model & Slope Walk Speeds & $15 \mathrm{~m}$ & STRM Imagery \\
Land Cover & Walk Speeds & $30 \mathrm{~m}$ & RCMRD Geoportal \\
Water Points & Boreholes, Springs & & WRMA \\
Aerial Imagery & Household Location & $15 \mathrm{~m}$ & Multiplex Ltd \\
& Built-up Areas & $15 \mathrm{~m}$ & Multiplex Ltd \\
Government & Government & & $\begin{array}{c}\text { Obtained from Landcover (forests, } \\
\text { water bodies, settlement schemes) }\end{array}$ \\
\hline Designated Areas & Directives & & w
\end{tabular}

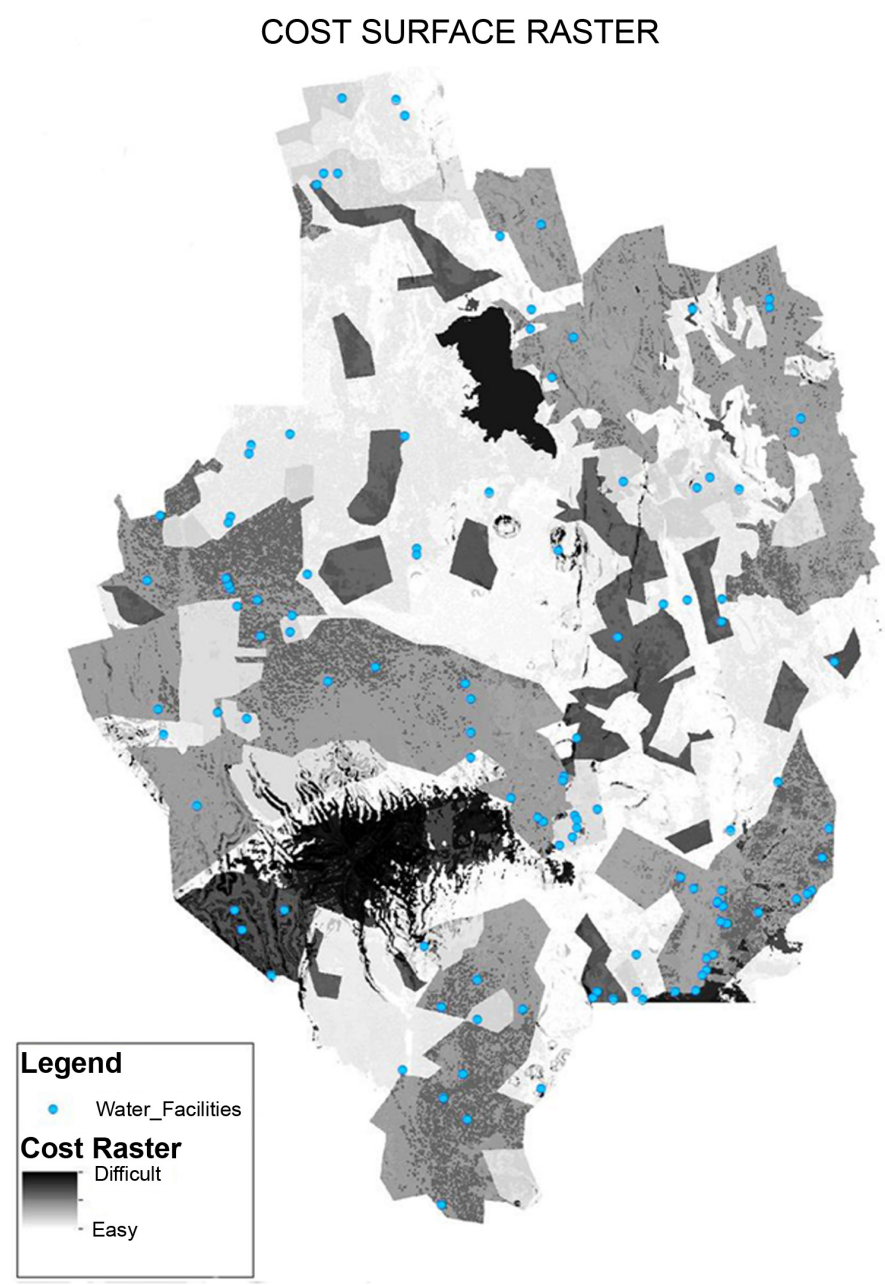

Figure 4. Cost surface raster.

For raster cells with the value of 10, which are areas with difficulty of movement like water bodies, when a weighted overlay was done the overall value after the evaluation remains 10 regardless of the other cell values allocated to the other features as shown in Table 6. In this evaluation land cover had the biggest 
Table 6. Sampled weighted points.

\begin{tabular}{ccccc}
\hline ID & Land Cover & Slope & Built-up Area & Evaluate \\
\hline 0 & 8 & 2 & 8 & 8 \\
2 & 7 & 2 & 8 & 7 \\
10 & 3 & 2 & 8 & 3 \\
15 & 3 & 1 & 8 & 3 \\
51 & 5 & 3 & 1 & 5 \\
100 & 3 & 1 & 3 & 3 \\
110 & 8 & 1 & 5 & 8 \\
151 & 10 & 1 & 8 & 10 \\
167 & 5 & 9 & 8 & 8 \\
205 & 8 & 10 & 8 & 10 \\
222 & 4 & 8 & 1 & 4 \\
251 & 9 & 1 & 1 & 9 \\
\hline
\end{tabular}

influence followed by slope value. Service areas from water facilities were created within travel time zones of 10, 20 and 30 minutes of walk time using road network speeds as an impedance having eliminated the main roads from the analysis referring to walk speeds in Table 3 .

Restricted layers were also used during the generation of service areas shown in Figure 5 which included forested areas and lakes. The Service areas were created to establish settlements that lived outside these zones and try to establish other sources of water for these settlers. Once the service areas were identified the study set to examine other factors that influence settlement apart from groundwater points since there were plenty of settlements in areas that had no groundwater points.

A predictive analysis using logistic regression was used to determine factors affecting settlement and the predictors used were; slope, agricultural areas (selected from land cover), transportation (roads and railway), groundwater points, government policy (forests and settlement schemes) and soil type. Logistic regression was used because the response to whether a variable affects settlement in an area was a dichotomy with a response of either yes or no. Logistic Regression was well suited to describe and test hypothesis about existing relationships from the categorical outcome variable and several predictor variables [22].

The analysis used 240 observations which were generated randomly in the study and the values generated were binary $(1,0)$ where Yes responses represented 1 and No 0 . R software was used in the analysis using Logistic regression since the response values were either yes or no (settlements were present in certain conditions).

Null deviance and the residual deviance from Table 9 shows how well the model fits against the null model which is a model with only the intercept whereas the gap widens the better the fit. The drop in the deviance value is experienced when adding a variable which reduces the value of the residual deviance. 


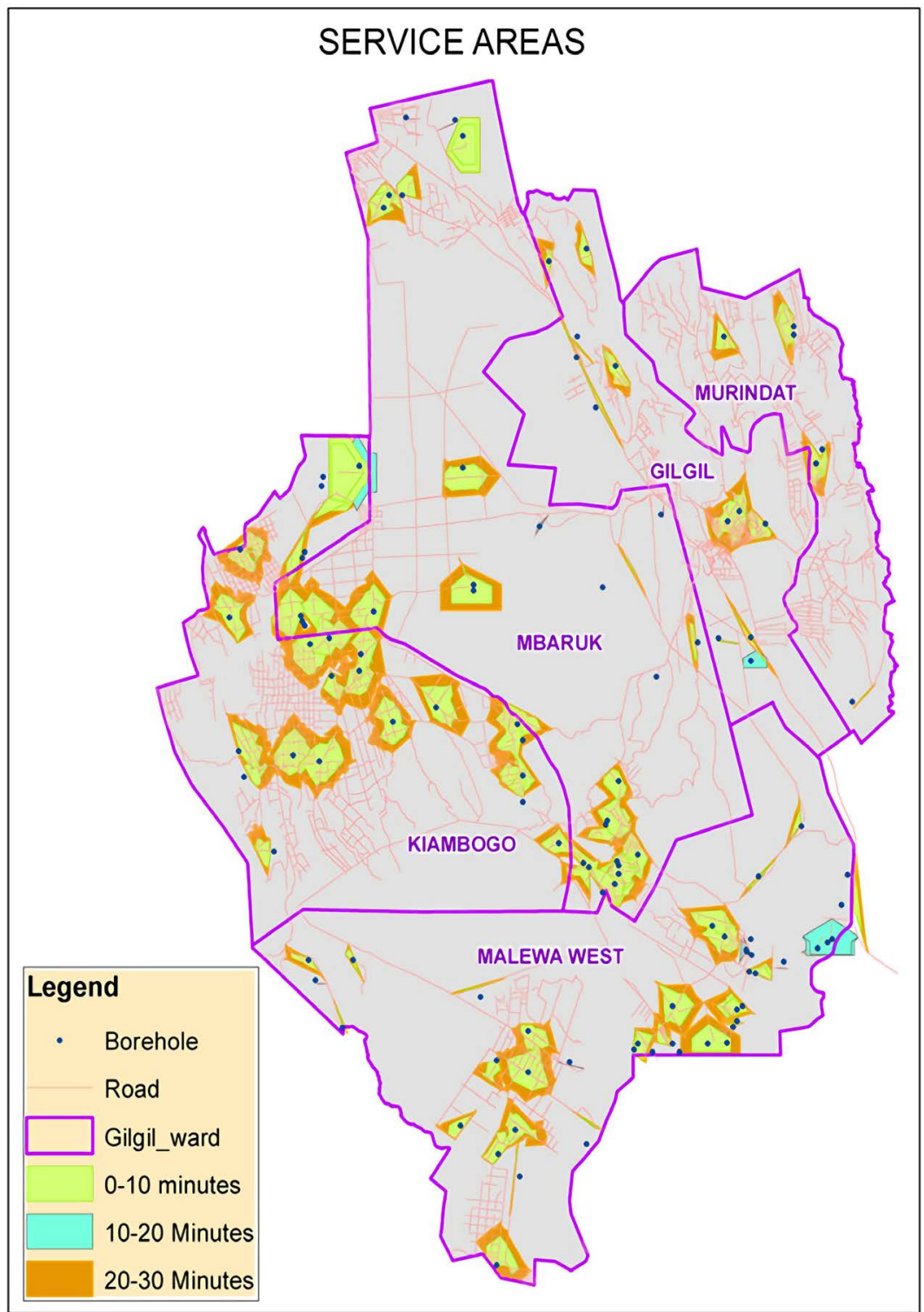

Figure 5. Walk time service areas and water facilities.

When a variable has p-value that has no significance shown by Table 7, Table 8 and Figure 6, the variable should be dropped from the model to further improve the model fit and a better fit will reflect to a significant drop in deviance and Akaike information criterion (AIC) and a lower AIC means the model is closer to the truth.

\section{Results}

\subsection{Travel Cost Results}

The results of Figure 4 and Table 10 show a cost surface which was generated using weighted sum overlay that allowed for variables to be allocated varying importance and therefore logic was observed especially in areas that pedestrians could not walk over due to the presence of water bodies, swamps or very high 
Table 7. Logistic regression significance results.

\begin{tabular}{ccccc}
\hline Estimate & Std Deviation & Error & Z-Value & P-Value \\
\hline Intercept & -1.82 & 0.69 & -2.64 & $0.00828^{* *}$ \\
Govt Directive & 0.83 & 0.35 & 2.35 & $0.01881^{\star}$ \\
Soil & -0.92 & 0.51 & -1.81 & 0.06968 \\
Infrastructure & 1.53 & 0.36 & 4.2 & $2.62 \mathrm{e}-05^{\star * *}$ \\
Water Sources & 1.13 & 0.48 & 2.32 & $0.02016^{\star}$ \\
Agriculture & 0.7 & 0.3 & 2.364 & $0.01837^{*}$ \\
Slope & 0.47 & 0.3 & 1.62 & 0.1064 \\
\hline
\end{tabular}

Table 8. Logistic regression.

\begin{tabular}{|c|c|c|c|c|c|c|}
\hline \multicolumn{7}{|c|}{ Logistic Regression Results. } \\
\hline $\begin{array}{l}\text { Significance } \\
\text { codes: }\end{array}$ & 0 “***»" & $0.001 “ * * »$ & 0.01 “»” & 0.05 “.” & 0.1 “” & 1 \\
\hline Significance: & Significant & Significant & Significant & $\begin{array}{c}\text { Significance } \\
\text { Cut-off }\end{array}$ & $\begin{array}{c}\text { Not } \\
\text { Significant }\end{array}$ & $\begin{array}{c}\text { Not } \\
\text { Significant }\end{array}$ \\
\hline
\end{tabular}

Table 9. Deviance results.

Deviance Results.

Null deviance: 332.44 on 239 degrees of freedom

Residual deviance: 279.38 on 234 degrees of freedom

AIC: 291.38

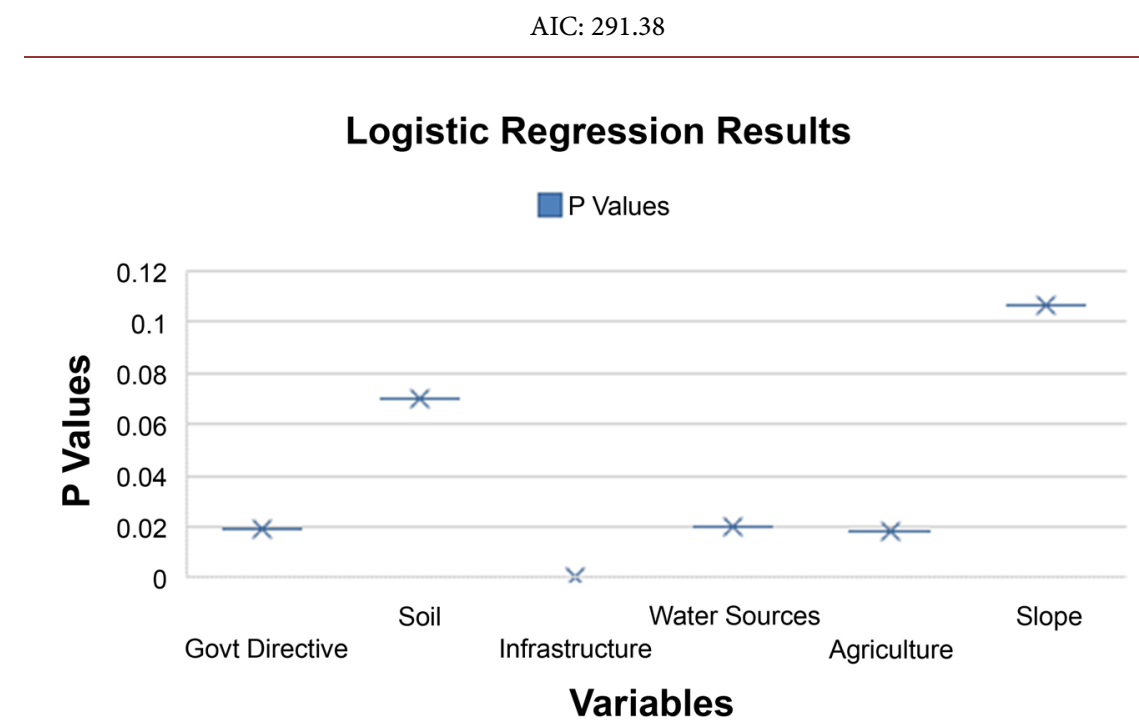

Figure 6. Logistic regression chart.

peak slopes. The use of Visual Basic scripts during the overlay outperforms a normal overlay that does not create conditions and simply averages all the raster's cell values that are involved in the analysis.

Cost surface was generated to explain ease of pedestrians moving across the wards in Gilgil constituency. Table 10 depicts that Kiambogo ward had the 
Table 10. Travel cost percentages.

\begin{tabular}{cc}
\hline Ward & Travel Cost Percentage \\
\hline Mbaruk & 6.9 \\
Gilgil & 11.2 \\
Malewa West & 18.3 \\
Murindat & 25.7 \\
Kiambogo & 37.9 \\
\hline
\end{tabular}

highest surface friction covering $37.9 \%$ of the total friction surface and Mbaruk Ward the lowest surface friction of $6.9 \%$.

\subsection{Service Area Results}

From the three service walk zones created, consideration was given to the maximum walk time that WHO recommended would be good for pedestrian to endure which was 30 minutes. From Figure 7 out of a total of 36,109 semi-permanent structures in the study area, only a total of 8195 households were within the 30 -minute walk time which is $23 \%$.

Households that are within 30-minutes form the bulk with 4335 households while those within 10 minutes of walk time are 3828 . The service areas are well concentrated in regions that have croplands which are Murindat, Malewa West and Kiambogo while areas with no service area have wooded and open grassland, lake and forests which explains lack of settlements in those areas demonstrated in Figure 3. The areas in Murindat and Kiambogo with settlements and no service areas have huge river networks hence presence of alternative water sources. The study was concerned with groundwater sources only, thus excluded other available water sources.

\subsection{Logistic Regression Results}

From the prediction analysis, there was a decrease in deviance from the null value of 334 to residue deviance of 279 which is a reduction of 53.06 points on 5 degrees of freedom which is a significant reduction. Such reduction in deviance shows a good fit of the model. The Akaike Information Criterion (AIC) is another result obtained in R and it assesses model quality; where a low AIC would depict greater model quality. In the study the AIC was 291.38 as shown in Table 9 and we further improved the model by eliminating any variable that was not significant. In this study, slope has no significance as shown from its $\mathrm{p}$ value not having an asterisk hence was removed and the AIC value reduced to 283.41.

The variable having the highest influence as shown in Table 7 is Infrastructure given its p-value has significance indicated by the 3 asterisks. Other variables with influence are Agricultural Zones, Water locations and Government Policy. From analysis, slope and soil do not necessarily control settlement especially if other factors override them like the government policy. Example; in Kiambogo the government created a settlement scheme; Eburru Settlement Scheme 


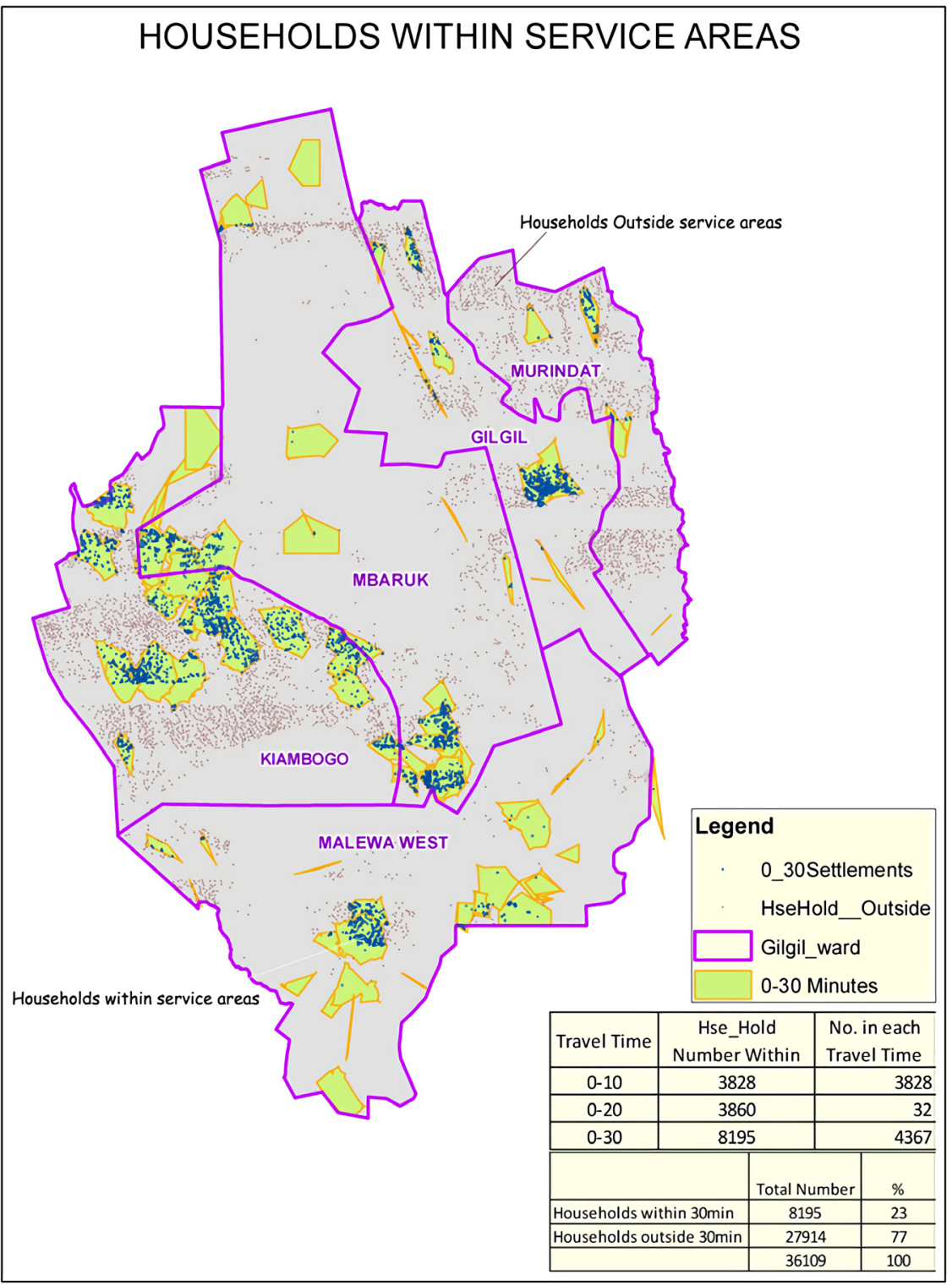

Figure 7. Households within and outside the service areas.

(Olrajai Scheme) at the top of Eburru range which attracted settlement though the area has less water facilities.

\section{Discussion}

The study shows that a high travel cost does not necessarily translate to lack of access while low travel costs may not necessarily translate to high settlement or presence of water facilities. An example is Kiambogo ward which has high travel cost and equally has the highest number of service areas which can be attributed to the good road network. The service areas are well concentrated in regions that have croplands which are Murindat, Malewa West and Kiambogo while areas with no or less service areas have wooded and open grassland, lake and forests which explains lack of settlements in those areas. The areas in Murindat and 
Kiambogo with settlements and no service areas have huge river networks as shown in Figure 2 hence the population depends on alternative water sources as shown from Table 1.

Analysis results from Table 7, slope and soil do not necessarily control settlement especially if other factors override them like the government policy. Example; in Kiambogo the government created a settlement scheme; Eburru Settlement Scheme (Olrajai Scheme) at the top of Eburru range which attracted settlement though the area has less water facilities [23].

Water accessibility study previously conducted by Ntozini, stated that most households experienced hardship in accessing water [12] and service areas were linked to health risks which is similar to the study in Gilgil, though our study mainly dealt with access and service areas to determine gaps but not linked to health. In Gilgil out of a total of 36,109 semi-permanent structures captured in the study 27,914 were outside the 30 -minute walk time, which is $77 \%$ of the households. Our study determined the population in need of accessing water using aerial imagery with a resolution of $15 \mathrm{~m}$ which makes identification of features easy and more accurate. This study also used road walk time as a cost in creation of service areas compared to Ntozini's study which used Google Earth whose resolution in some cases can be low as well as used shortest distance without consideration of impedance.

This study is significant because Gilgil constituency receives bi-modal rains which are neither heavy nor reliable and therefore experiences water stress. A study on service area gaps is thus important to ensure the entire population easily obtains this essential commodity. Besides, no study on water accessibility had previously been conducted in Gilgil and areas lacking service areas can be explained using other variables. This study therefore enables water stakeholders understand gaps in water provision and effectively make decisions on future services or management programs.

\section{Conclusions}

In conclusion, access to water should emphasize on accessing an improved source that is safe for drinking and as a result, this study only focused on water points obtained from WRMA, a state corporation whose principal mandate is to work as a lead agency in management of water resources in the country. The study mainly concentrated on accessibility with the assumption that water points observed and monitored by WRMA had some acceptable levels of quality for them to still be functional. Working only with the population living in semi-permanent structures, the study classifies the population to be that of the poor. This selected population lack piped water or trapped water connected to their dwelling and mostly obtain water from a water vendor, borehole, spring or river and that is the reason why this study has emphasis on walk distance towards the water source.

This study therefore enables various stakeholders to make policy decisions or 
investments, knowing where a service is needed the most using the gaps shown by service areas concentrated in regions with less or no impediments. The service areas would have been more accurate if the roads were finely digitized to include the in-roads that locals probably use but are not designated as trails.

For future studies, further advancement can be done by categorizing the population accessing the groundwater facilities to gender brackets as the African culture has mainly allocated this task to children and women. Rivers should also be included in development of service areas since groundwater is not the only source. Water quality of the ground points should also be included so that despite ascertaining accessibility depending on time only as the cost, the quality of water can be categorized.

\section{Acknowledgements}

I wish to acknowledge the help provided by Multiplex Limited by allowing me to make use of their aerial images to digitize households and Water Resource Management Authority (WRMA) office located in Naivasha for providing me with water facility data that was geo-referenced. My appreciation also goes out to all my work colleagues who assisted me with data preparation and analysis techniques as well as some of my former classmates who assisted with data interpretation in the early stages of my project and software use advise. I am equally thankful for the guidance from my university supervisors who assisted in research conceptualization, methodology, validation process, providing critical comments resulting in revisions to content and drafting of the manuscript.

\section{Conflicts of Interest}

The authors declare no conflicts of interest regarding the publication of this paper.

\section{References}

[1] Institute of Economic Affairs (2007) A Rapid Assessment of Kenya's Water, Sanitation and Sewerage Framework.

[2] United Nations (2014) The United Nations World Water Development Report 2014, Water and Energy.

[3] Winpenny, J. (2009) Investing in Information, Knowledge and Monitoring the United Nations World Water Development Report 3 Water in a Changing World.

[4] Gleeson, T., Wada, Y., Bierkens, M.F.P. and Van Beek, L.P.H. (2012) Water Balance of Global Aquifers Revealed by Groundwater Footprint. Nature, 488, 197-200. https://doi.org/10.1038/nature11295

[5] UN-Water (2006) Facts and Trends: Water.

[6] World Health Organization and UNICEF (2006) Meeting the MDG Drinking Water and Sanitation: The Urban and Rural Challenge of Decade.

[7] Cairncross, S. (2002) Sanitation and Water Supply: Practical Lessons from the Decade, Vol. 17.

[8] Banerjee, S.G., Morella, E. and Banerjee, S.G. (2011) Africa's Water and Sanitation 
Infrastructure-Access, Affordability, and Alternatives. Vol. 1, Report No. 60804. https://doi.org/10.1596/978-0-8213-8457-2

[9] Ministry of Environment Water and Natural Resources (2013) National Environment Policy, 2013.

[10] Ministry of Water and Irrigation (2010) Annual Water Sector Review 2009. January.

[11] Government of Kenya (2002) The Water Act of Kenya 2002. No. 8.

[12] Ntozini, R., et al. (2015) Using geographic Information Systems and Spatial Analysis Methods to Assess Household Water Access and Sanitation Coverage in the SHINE Trial. Clinical Infectious Diseases, 61, S716-S725. https://doi.org/10.1093/cid/civ847

[13] Thompson, A.O. and Dodson, R.G. (1963) Ministry of Natural Resources, Geological Survey of Kenya. Government of Kenya.

[14] Wagah, G.G., Onyango, G.M. and Kibwage, J.K. (2010) Accessibility of Water Services in Kisumu Municipality, Kenya. Journal of Geography and Regional Planning, 2, 114-125.

[15] Njonjo, K.S. (2013) Pulling Apart or Pooling Together? Kenya National Bureau of Statistics (KNBS) and Society for International Development (SID).

[16] Kiti Nabide, I. (2002) Development of 3-D Conceptual Hydrogeological Model for Lake Naivasha Area. Unpublished Master's Thesis, International Institute for Aerospace Survey and Earth Sciences, Netherlands.

[17] Mailu Stephen, R.E., Bernard, K. and Wilfred, N. (2010) Effect of Cropping Policy on Landowner Reactions Towards Wildlife:a Case of Naivasha. Word: Journal of the International Linguistic Association, No. 21308.

[18] Jaetzold, R. and Schmidt, H. (1983) Natural Conditions and Farm Information Part B, Vol. II.

[19] Pozzi, F. and Robinson, T. (2008) Accessibility Mapping in the Horn of Africa: Applications for Livestock Policy. No. 11-08, 43.

[20] Alegana, V.A., Wright, J.A., Pentrina, U., Noor, A.M., Snow, R.W. and Atkinson, P.M. (2012) Spatial Modelling of Healthcare Utilisation for Treatment of Fever in Namibia. International Journal of Health Geographics, 11, 6. https://doi.org/10.1186/1476-072X-11-6

[21] Pozzi, F., Robinson, T. and Nelson, A. (2010) Accessibility Mapping and Rural Poverty in the Horn of Africa. No. 47, 35.

[22] Peng, C.-Y.J., Lee, K.L. and Ingersoll, G.M. (2002) An Introduction to Logistic Regression Analysis and Reporting. The Journal of Educational Research, 96, 3-14. https://doi.org/10.1080/00220670209598786

[23] Kahenda, M. (2019) ADC Asked to Provide Information to Speed up Investigations on Land Fraud.

https://www.standardmedia.co.ke/article/2001308779/sleuths-probe-adc-land-grabb ing 